\title{
Empowerment and participation by the means of Citizen Science - Methodological approaches and experiences from projects in rural areas
}

\author{
Marika Gruber $^{a *}$ and Gabriele Hagendorfer-Jauk ${ }^{b *}$ \\ aCarinthia University of Applied Sciences, School of Management, \\ Europastraße 4, 9524 Villach, Austria \\ bCarinthia University of Applied Sciences, School of Health and Social Sciences, \\ Hauptplatz 12, 9560 Feldkirchen in Kärnten, Austria \\ E-mail: m.gruber@fh-kaernten.at,g.hagendorfer@fh-kaernten.at
}

This article discusses the individual, social and democratic potentials of participation in Citizen Science projects. It has been investigated whether and to what extend Citizen Science participation can foster individual empowerment, self-advocacy, political participation and community capacity building for vulnerable groups. Experiences and impacts derived from two recently finished practice projects in rural areas of Carinthia, which aimed to promote the inclusion and equity of chances for people with a migrant background as well as elderly people with dementia and their caregivers, are reflected and discussed. The results show that (Citizen Science) research is able to help in giving disadvantaged groups a voice and the possibility of participation in the community. 


\section{Introduction}

The scientific debate on participation is increasingly associated with the discussion on participation of citizens in research activities. Reference is made to the question what participation means in the concept of Citizen Science or Participatory Research, which is the approach more commonly referred to in Social Sciences [1]. According to Finke [2], the strengthening of civic engagement in the civil society is the greatest opportunity of Citizen Science, since the complementarity of professionals and lay people is vital. Practical knowledge as well as practiceoriented, near-term and local solutions cannot be generated without the involvement of citizens in their living environment.

The focal points of discussion at the Austrian Citizen Science Conference 2020 were aspiration, importance and meaning of Citizen Science. This article takes up these matters in relation to the individual, social and democratic potentials of participation in Citizen Science. It investigates under which circumstances Citizen Science participation can foster individual empowerment, self-advocacy, political participation and community capacity building activities towards the development of "caring communities". Experiences and impacts derived from two recently finished practice projects in rural areas of Carinthia, which aimed to promote inclusion and equity of chances for vulnerable groups - people with a migrant background as well as elderly people with dementia and their caregivers -, are reflected and discussed.

\section{Theoretical background}

Two theoretical concepts are formative for this contribution: the concept of empowerment and the concept of capacity building. Both determining concepts are transferred to the local/community level and applied to two different groups: people with a migrant background and elderly people.

In psycho-social practice, self-empowerment means the strengthening of people's autonomy and self-power. Empowerment aims to encourage people to discover their own strengths and at the same time supports them in acquiring self-determination and autonomy [3]. Finally, selfempowerment should also lead to political empowerment and the capacity to participate in political decision-making [4].

With the community capacity building approach, efforts go beyond individual-centered approaches to empowerment towards the development of capacity in the community/ neighbourhood [5]. Chaskin et al. [6] see it as the ability (capabilities) to promote or maintain the well-being of communities, based on existing community resources (e.g. competences and skills of community members), relationship networks (formal-institutional, informal, emotional), leadership and support for participatory processes.

Empowerment, co-determination, social participation, the creation of spaces for encounters as well as the strengthening of the community capacity in regards to vulnerable target groups were central in the two projects discussed.

\section{Citizen Science approaches fostering empowerment and participation}

Migrants are often confronted with a devaluation of qualifications and non-recognition of education, permanent pointing out of inadequacies and deficiencies lead to an infantilization of migrants who are thus forced into dependency. Due to their non-Austrian nationality, around 
1.5 million people (by 1.1.2020) in Austria are not represented in political decision-making processes [7].

The change in the population age structure and the resulting forecasts regarding the increase of dementia (in Austria, due to estimates, about 260,000 people will be affected by 2050 [8]) are mainly described as a challenge for society, especially in connection with increased care needs. Moreover, a retreat to the private living space by those affected and their relatives for fear of social stigmatization can be observed [9].

Following this discussion, the question is: how can (Citizen Science) research help to give disadvantaged groups a voice and the possibility of participating in the community?

The rural social innovation project "...come to stay... Immigration as a potential for the Hermagor region" (co-financed by the LEADER fund, led by the Carnic Regional Association of Municipalities) aimed to develop services in a standardized, regionally-coordinated quality level for international and internal migrants moving to the Hermagor district (Carinthia). Citizens and stakeholders, like local politicians, administrative staff, regional integration actors, such as staff from schools and training institutes, the police, the public employment service and physicians as well as people with and without a migrant background, including people who had moved away and returned again, were invited to take part in the elaboration of project results. In collaboration, needed working materials for civil servants (checklist for coordinated information and counselling of newcomers), an infosheet for newcomers (first steps after settling down in a new municipality) and a collection of suggested improvements have been developed. Different methods as feedback sessions to validate (intermediate) results, workshops to participatorily elaborate practical results, group work sessions to stimulate a "change of perspective" and networking meetings were applied.

Involving people with a migrant background in the formulation of measures that shape their living environment allows them to discuss and share their own experiences at eye level with other members of the local community, to engage in conversation with local people and thus contribute to reducing possible reservations. The active involvement of migrants and local community members gives them a voice and lets them represent themselves.

The health promotion project "Dementia-friendly Community Moosburg", co-financed by the Fund for a Healthy Austria, aimed to activate solidarity and civic engagement as well as to promote social embedding and participation of people with dementia and their caregivers. Open activation and participation procedures were used, such as an open citizens' forum, a stakeholder workshop, a future conference and other events for the general public. In addition to various training concepts for caring relatives, professional groups working in the public sector and the training for voluntary dementia support, inclusive meeting spaces, like the dementia café or the generation café, were anchored in the long term. The participatory accompanying research and evaluation involved affected persons, carers, practice partners and citizens in an integrative project reflection. The positive acceptance and sustainable anchoring of the activities, the longterm commitment of stakeholders and the participation of affected families together with nonaffected families point to the positive developments towards a caring community.

\section{Conclusions}

In conclusion, the involvement of disadvantaged groups, as migrants often can be, in participatory (Citizen Science) research can mean articulating their own experiences and needs 
(being able to speak for themselves) as well as promoting communication at eye level, the equivalence of opinions (being heard) and creating a resource-based approach in which one's own knowledge and competences can be demonstrated. For members of the local community, the inclusion of disadvantaged population groups in research settings can mean raising awareness of otherwise often unrepresented/unseen population groups, reflecting on one's own attitudes, deconstructing the "unknown stranger" and breaking down prejudices. The same applies to the coexistence of those affected and not (yet) affected by dementia. A respectful and sensitive approach in dealing with dementia in everyday life requires a societal development. The strengthening of civil society participation and the assumption of responsibility in the sense of community capacity building can be seen as a suitable impetus in this direction.

\section{References}

[1] L. Pettibone \& D. Ziegler, Citizen Science: Bürgerforschung in den Geistes- und Kulturwissenschaften, in K. Oswald \& R. Smolarski (Eds.), Bürger Künste Wissenschaft: Citizen Science in Kultur und Geisteswissenschaften, pp. 57-69, Computus, Gutenberg 2016 [DOI: https://doi.org/10.22032/dbt.39056, accessed last: 05.01.2021].

[2] P. Finke, Citizen Science. Das unterschätzte Wissen der Laien, oekom, München 2014.

[3] T. Bartscher \& R. Nissen, Gabler Wirtschaftslexikon, Stichwort „Empowerment “, (2018), [https://wirtschaftslexikon.gabler.de/definition/empowerment-32955/version-256485, accessed last: 11.01.2021].

[4] OECD, Promoting Pro-Poor Growth. Policy Guidance for Donors, OECD, Paris 2007 [https://www.oecd-ilibrary.org/docserver/9789264024786en.pdf? expires $=1610402961 \&$ id $=$ id\&accname $=$ guest \&checksum $=$ A8E03C38CC92F6F7A8DF061E D8445ACB, accessed last: 11.01.2021].

[5] H. Penz, Gemeindebezogene Gesundheitsförderung. Eine Fallstudie zu etablierten Konzepten landesweiter Umsetzung, Verlag für Sozialwissenschaften, Wiesbaden 2008.

[6] R.J. Chaskin, P. Brown, S. Venkatesh \& A. Vidal, Building Community Capacity, Walter de Gruyter, New York 2001.

[7] Statistik Austria, Bevölkerung zu Jahresbeginn 1982-2020 nach Bundesländern und Staatsangehörigkeit, Statistik Austria, Wien 2020

[http://www.statistik.at/wcm/idc/idcplg?IdcService=GET_NATIVE_FILE\&RevisionSelectionMetho $\mathrm{d}=$ LatestReleased\&dDocName=108123, accessed last: 15.09.2020].

[8] S. Höfler, T. Bengough, P. Winkler \& R. Griebler (Eds.), Österreichischer Demenzbericht 2014, Bundesministerium für Gesundheit und Sozialministerium, Wien 2015 [https://goeg.at/sites/goeg.at/files/2017-06/oesterreichischer_demenzbericht_2014.pdf, accessed last: 05.12.2020].

[9] F. Kolland \& J. Hörl, Soziale Aspekte der Demenz, in S. Höfler, T. Bengough, P. Winkler \& R. Griebler (Eds.), Österreichischer Demenzbericht 2014, pp. 137-142, Bundesministerium für Gesundheit und Sozialministerium, Wien 2015 [https://goeg.at/sites/goeg.at/files/2017-06/oesterreichischer_demenzbericht_2014.pdf, accessed last: 05.12.2020]. 